\title{
CHEMICAL AND BIOLOGICAL POTENTIAL OF PASSIFLORA VITIFOLIA FRUIT BYPRODUCTS COLLECTED IN THE COLOMBIAN CENTRAL ANDES
}

\author{
JENNY AVILA*, ANGEL JIMÉNEZ, JONH MÉNDEZ, ELIZABETH MURILLO \\ Department of Chemistry, Natural Products Research Group (GIPRONUT), Science School, University of Tolima, Ibagué, Colombia, \\ Calle 42 \#1b-1. Email: jaavilao@ut.edu.co
}

Received: 30 July 2020, Revised and Accepted: 10 November 2020

\section{ABSTRACT}

Objective: The objective of the study was to establish potential uses of the fruit peel and seeds from Passiflora vitifolia collected in the Colombian Central Andes.

Methods: The physical characteristics and chemical profile of the byproducts were determined. The ethanolic extracts of these materials were used to assess the content and phytophenols composition, to establish the antioxidant potential and the antidiabetic activity, in vitro inhibition of $\alpha$-amylase enzyme and glucose diffusion. The performance and physicochemical composition of the seed oil was also evaluated.

Results: The seeds contain almost 4 times more phenolic compounds (10 $671 \mathrm{mg} \mathrm{GAE} / 100 \mathrm{~g}$ sample) than the peel (2817 mg GAE/100 g sample). Likewise, crude protein and fat contents from the seeds are higher (15.5\% and $25.6 \%)$ than the peel $(6.60 \%$ and $5.70 \%$, respectively). Nine phytoconstituents were positive for both extracts. Significant variation $(\mathrm{p}<0.05)$ of antioxidant and anti-hyperglycemic potential was observed among the peel and seeds in all methods applied.

Conclusion: Results showed that the byproducts of $P$. vitifolia fruit could be used to enhance the nutritional quality of functional products. These findings were also confirmed by the ethanolic extract from seeds, which revealed high levels of phenolics, high antioxidant potential, and antihyperglycemic activity that make it a promising phytotherapeutic product, all of which gives added value to the fruit of this wild Passiflora.

Key words: Passiflora vitifolia, Phenolic Compounds, Antioxidant Capacity, Anti-hyperglycemic activity, Colombian Andes.

(C) 2021 The Authors. Published by Innovare Academic Sciences Pvt Ltd. This is an open access article under the CC BY license (http://creativecommons.org/ licenses/by/4.0/) DOI: http://dx.doi.org/10.22159/ajpcr.2021v14i1.39277. Journal homepage: https://innovareacademics.in/journals/index.php/ajpcr

\section{INTRODUCTION}

According to the Alexander von Humboldt Biological Resources Research Institute, Colombia has approximately 170 Passiflora species, among which 45 are exclusive of the Andean region. Some of them are prominent for internal consumption and with export potential [1]. Despite these facts, the literature survey has revealed that several fruits are not available in our market, many others remain anonymous and very little work has been done on wild passionflower species, as in the case of Passiflora vitifolia (granadilla de monte or güillita). It is one of the more than 530 species that form Passiflora genus (Passifloraceae), distributed mainly in the New World [2]. This is an exotic plant that grows very easily in warm areas and tropical climates, native to southern Central America and northwestern South America. It is also found with a lower frequency in Australia, Africa, or Asia [3].

Previous works carried out in our research group allow us to describe P. vitifolia, developed in Ibagué-Tolima-Colombia, as a climbing vine of wild habitat; its leaves are characterized for having tomentose pubescence and coriaceous texture; the stems are cylindrical (terete) and of ferruginous coloration that reaches up to $8 \mathrm{~m}$ in length. The plant produces markedly different leaf morphology between the juvenile and adult stage (heteroblasty). The fruit is an indehiscent (6-7 cm long and $4.50 \mathrm{~cm}$ diameter) and egg-shaped berry, it has an edible part enclosed in a tough leathery pericarp (58 $\mathrm{mm}$ thickness); when unripe, it is green with white spots, quite sour still when it falls off the plant (climacteric) and it can take a month to ripen to its full flavor of sour strawberries; as it ripes, the coloration of the epicarp varies from slightly yellow to dark brown and accompanied by loss of water so that the fruit loses texture and looks wrinkled. The ripe fruit is perfumed, bittersweet, and has good nutritional content.
The edible part contains $240-330$ seeds $(0.70 \mathrm{~cm}$ long and $0.45 \mathrm{~cm}$ diameter) per fruit embedded in the pulp rich in $\mathrm{A}$ and $\mathrm{C}$ vitamins. The seed retains the shape of the fruit, has a non-cross-furrowed reticulealveolate surface, hornless apex, and striated margin. The anatomy of the seminal cover may have taxonomic identification value [4] The big deep, bright red of the flowers (scarlet passion flower) and the bracts of great size, colored and with smaller glands in the margin, are additional characteristics that would allow to $P$. vitifolia distinguishable from other Colombian passion flowers.

Nevertheless, the use of P. vitifolia fruit is limited in Colombia due to its low productivity and poor market linkage, even remaining as a wild plant. The main ethnomedical use of this species is an infusion of the dried plant and the scarlet flower tinctures [5]. Flavones-Cglycosides, C-glycosylflavonoids, and cyanogenic glycosides were found in our country as the main constituents of hydroalcoholic extract from P. vitifolia leaves [6]. Just the same, Jimenez Rodriguez [7] evaluated the antihypertensive and antioxidant capacities of the ethanolic extract obtained from the seeds of $P$. vitifolia Kunth.

This study was designed to assess the physical characteristics, chemical properties, and biological potential of the peel and seeds from $P$. vitifolia fruits collected in the Colombian Andean central region. The physicochemical characterization of fatty oil extracted from its seeds was studied. This new information on Passiflora may provide insight on its pharmacological properties and its use in the development of new functional products of importance in various industrial fields, as well as generate additional value to the fruit byproducts in the possibility of its industrialization. The production of large amounts of plant derivatives leads to economic losses and environmental pollution, which should make the use of these residues attractive to the industry to increase cost-effectiveness. 


\section{METHODS}

\section{Chemicals and reagents}

All reagents and solvents used were of analytical grade unless otherwise specified. Other chemicals and reagents, such as for high-performance liquid chromatography (HPLC), CG analysis, and antioxidant and hyperglycemic activities, were obtained from SIGMA-ALDRICH (St. Louis, MO, USA).

\section{Plant material collection}

P. vitifolia ripe fruits were collected at the proper time (December 2018) with suitable methods [8] in the botanical garden Alejandro von Humboldt at University of Tolima (UT), located in Ibagué (1170 m.a.s.l., $27^{\circ} \mathrm{C}$ ). The sample was randomly taken, considering the four cardinal points from shrubs available until completing a total of 30 individuals in optimal phytosanitary status. Collecting Permit for the UT: Resolution No. 02191, November 27, 2018 - Framework Permit - ANLA and Resolution No. 00472, March 27, 2019. The plant was determined and identified at the National of Colombia herbarium with the name of P. vitifolia Kunth.

Physical and chemical characterization of the fruit byproducts To establish some additional parameters of the peel and seeds, color parameters $(\mathrm{n}=25)$ were assessed using a reflectance spectrophotometer (Spectrophotometer CM 5, Konica Minolta, Tokyo, Japan), the results were expressed according to the CIELAB color system ( $\mathrm{L}^{*}=$ lightness, $\mathrm{a}^{*}=$ redness, and $\mathrm{b}^{*}=$ greenness). P. vitifolia epidermis texture was measured using a texturometer (LS1 Lloyd, AMETEK Inc, Pennsylvania, PA, USA), with a speed of $2 \mathrm{~mm} / \mathrm{s}$, and compression of $20 \mathrm{~mm}$ [9].

\section{Preparation and evaluation of total soluble extractives (TSEs)}

Peel and seeds were manually separated from the pulp, dried on the stove $\left(45 \pm 2^{\circ} \mathrm{C}\right)$, and milled to obtain a homogeneous flour that was degreased with n-hexane using the conventional Soxhlet extraction apparatus. The quantification of TSEs was carried out extracting the degreased flour by sonication-assisted $(15 \mathrm{~min}$., pulses $10 \mathrm{~s}$., rest 5 s., amplitude 70\%; FISHER SCIENTIFIC device Model FB505, $20 \mathrm{kHz}$ frequency, Pittsburgh USA). About $96 \%$ ethanol and ethyl acetate were used individually for extraction at a sample-to-solvent ratio of 1:100 $(\mathrm{w} / \mathrm{v})$. Three separate extractions for each solvent were conducted in parallel on peel and seed samples. The extracts were evaporated (Buchi $\mathrm{R}-215)$ under vacuum $\left(40^{\circ} \mathrm{C}\right)$. Afterward, an aliquot $(1 \mathrm{ml})$ of each extract was taken, the solvent evaporated (vacuum desiccator, $27^{\circ} \mathrm{C}$ ), and oven-dried $\left(103 \pm 2^{\circ} \mathrm{C}\right)$ until a constant mass was reached. TSEs were expressed as a percentage $(\% \mathrm{w} / \mathrm{w})$.

\section{Extraction procedure of ethanolic extracts}

The extraction procedure was conducted from degreased plant material, which was macerated with $96 \%$ ethanol and occasional stirred $(24 \mathrm{~h})$, renewing the solvent every $2 \mathrm{~h}$. The extracts obtained were filtered and concentrated by a rotary vacuum evaporator (Rotavapor R-114, Büchi, Flawil, Sweden) under vacuum $\left(40^{\circ} \mathrm{C}\right)$ and stored in a deep freezer $\left(-80^{\circ} \mathrm{C}\right)$ until further analysis. During the research, the air temperature in the laboratory was $18 \pm 1^{\circ} \mathrm{C}$. The ethanolic extracts were selected for further analysis. The degreased powder was also kept in a refrigerator $\left(4^{\circ} \mathrm{C}\right)$ until required for use.

\section{Physical and chemical characterization of the ethanolic extracts}

The physical characteristics of extracts were determined using standard methods [10]. The preliminary phytochemical tests were performed to determine the presence/absence of different nucleus of secondary metabolites in the extracts $[11,12]$. An HPLC analysis was realized on a Waters Alliance e2695 separations module system (Waters Corporation, Milford, USA), coupled to a dual-channel $\lambda$ absorbance (320 and $280 \mathrm{~nm}$ ) detector, according to Delpino-Rius et al. [13]. The data acquired using the chromatographic behavior and UV-vis absorption spectra were contrasted with published data on the main phenolic compounds in the samples. The nutritional composition was determined in a portion of the degreased samples, for peel and seeds independently. The content of mineral elements (major and minor) was estimated using an atomic absorption spectrometer (Thermo Scientific iCE 3000 Series AA). The assessment of P, B, and S was established by UV-visible spectrophotometry (Thermo Scientific Evolution 600). The nutritional composition and mineralogical determinations were made according to official methods of analysis of AOAC [14].

Extraction and physicochemical characterization of the seed oil The oil extraction yield was estimated from dried seeds, prepared as described above; the extraction performance was expressed as a percentage $(\% \mathrm{w} / \mathrm{w})$. Theoil obtained was keptin the darkbottles, flushed with a nitrogen stream, sealed, and stored in a freezer $\left(-80^{\circ} \mathrm{C}\right)$. Fatty acid methylation from seed oil was achieved following the methodology described by Tomàs et al. [15]. The physicochemical characteristics of each oil were determined using standard methods [14]. An Agilent 6890 gas chromatograph with a flame ionization detector interfaced to a mass spectrometer (Agilent Technologies España, S.L., Las Rozas, Spain) was configured to determine the chemical composition [16]. Interpretation of the mass spectrum was conducted using the database of National Institute Standard and Technology (NIST), which has more than 62,000 patterns. The individual compounds were identified by comparing their fragmentation pattern spectra with those of authentic samples and data available in the NIST library [17]. The relative percentage of the identified compound was expressed as a percentage with peak area normalization.

\section{Estimation of total phenolics and Antioxidant potential}

The concentration of total phenolics of the samples was determined by the Folin-Ciocalteu assay [18]. Absorbance was measured at $725 \mathrm{~nm}$ on a UV-visible spectrophotometer (Thermo Scientific Evolution 600, USA). Total phenolic was expressed as Gallic Acid Equivalents per $100 \mathrm{~g}$ of sample (GAE.100/g sample). The total antioxidant potential (TAP) of the compounds present in the peel and seeds was measured using $\mathrm{DPPH}^{\bullet}[19]$ and 2,2'-azino-bis(3-ethylbenzothiazoline-6-sulphonic acid $\left(\mathrm{ABTS}^{\circ}\right)$ [20] radical scavenging capacity (RSC) assays. In another set of experiments, antioxidant capacity (AC) was performed evaluating the ferric reducing of antioxidant power (FRAP), according to Berker et al. [21]. The above assays were carried out in microplate spectrophotometers (96 wells microplate UV-vis reader). The oxygen radical absorbance capacity (ORAC) was also estimated (excitation wavelength of $493 \mathrm{~nm}$ and excitation slit 5, emission wavelength $515 \mathrm{~nm}$, and slit emission 13, with attenuator of $1 \%$ and without plate attenuator). Signals were recorded in a fluorescence spectrometer (PerkinElmer LS-55) with a thermostatted multicell, essentially as described by $\mathrm{Ou}$ et al. [22]. For each trial, various concentrations of Trolox standard solution (for construction of a standard curve) or blank (as a control) were placed in the individual wells on the respective device. All results were expressed as the concentration required for $50 \%$ inhibition of viability ( $\mathrm{IC}_{50} \mathrm{RSC}$ or $\mathrm{IC}_{50} \mathrm{AC}$ values).

\section{Anti-hyperglycemic activity}

An in-vitro study on alpha-amylase inhibitory activity was performed using the 3,5-dinitrosalicylic acid (DNSA) method [23]. To $100 \mu \mathrm{l}$ of $P$. vitifolia peel and seed extracts, the starch in phosphate buffer solution $(1 \% \mathrm{w} / \mathrm{v}, \mathrm{pH} 6.9)$ containing $6.7 \mathrm{mM}$ of sodium chloride to give $(100-800 \mu \mathrm{g} / \mathrm{ml})$ final concentration was added. The reaction was initiated by adding $100 \mu \mathrm{l}$ alpha-amylase enzyme (SIGMA- A6255) solution dissolved in the buffer (1:10, sample/solvent) and incubated $\left(37^{\circ} \mathrm{C}, 10 \mathrm{~min}\right)$. From the above mixture, $200 \mu \mathrm{l}$ were taken along with $500 \mu \mathrm{l}$ of DNSA ( $1 \mathrm{~g}$ of DNSA, $30 \mathrm{~g}$ of sodium potassium tartrate, and $20 \mathrm{ml}$ of $2 \mathrm{~N}$ sodium hydroxide was added and made up to a final volume of $100 \mathrm{ml}$ with distilled water) and kept it in a boiling water bath $\left(85-90^{\circ} \mathrm{C}\right.$, at this temperature the DNSA reagent forms a colored complex with the reducing sugars, the product of the previous enzymatic activity) for $15 \mathrm{~min}$. The reaction mixture was stopped by an ice bath diluted ( $2.7 \mathrm{ml}$ distilled water), and its absorbance was read at $540 \mathrm{~nm}$ using a UV-Visible spectrophotometer (Thermo Scientific Evolution 600, USA). For each concentration, blank tubes were prepared by replacing the enzyme solution with $100 \mu \mathrm{l}$ in distilled water. A control, representing $100 \%$ of the enzyme activity, was prepared similarly, without extract. 
The experiments were repeated thrice using the same protocol. The alpha-amylase inhibitory activity was calculated using formula 1.

$$
\% \text { Inhibition }=\frac{\text { Abs control }-(\text { Abs sample }- \text { Abs blank sample })}{\text { Abs control }}
$$

The effect of the extracts from the byproducts on a model on in-vitro glucose diffusion through a dialysis membrane was also applied [24]. This model simulates the absorption of glucose in the small intestine. Twenty-five milliliters of glucose solution $(20 \mathrm{mM})$ and the samples of plant extracts $(1 \%)$ were dialyzed in dialysis bags against $200 \mathrm{~mL}$ of distilled water $\left(37^{\circ} \mathrm{C}\right)$ in a shaker water bath. The glucose content in the dialysate was determined at 30 and $60 \mathrm{~min}, 2,6$, and $24 \mathrm{~h}$. The quantification of reducing sugars was carried out according to the DNS methodology [25]. A calibration curve was made with soluble glucose (125-2000 mg/l). A control test was carried out without a sample. Glucose dialysis retardation was calculated using formula 2 and expressed as a percentage.

$$
\% \text { Inhibition }=\frac{\text { Abs control }- \text { Abs sample }}{\text { Abs control }} \times 100
$$

\section{Statistical analysis}

All measurements were carried out on triplicate samples. Linear regression $\left(R^{2}\right)$ to calculate the $\mathrm{IC}_{50}$ values, Pearson's Correlation (R) to measure strength and direction $(-1>r<1)$ of the linear relationship between variables were performed with GraphPad 6.01 software (San Diego, Ca, USA). Mean \pm SD was used for multivariate analysis (ANOVA) with Tukey's post hoc test. The difference at $\mathrm{p}<0.05$ was considered statistically significant.

\section{RESULTS}

Physical characterization of peel and seeds

From the reflection spectrums, the color coordinates CIE $\mathrm{L}^{*} \mathrm{a}^{*} \mathrm{~b}^{*}$ of $P$. vitifolia peel and seeds were obtained, where $L^{*}(55.5 \pm 0.28)$ is related to white spots of peel, and parameter $\mathrm{a}^{*}=-3.80 \pm 0.17$ indicates the intensity of greenness. This suggests a high presence of chlorophyll pigments. Parameter $b^{*}=28.5 \pm 0.22$ (intensity of yellowness) designates the joint participation of carotenoid and anthocyanin pigments [9]. The color of $P$. vitifolia unripe fruit changes slightly during maturation (green-red); then, $\mathrm{a}^{*}$ and $\mathrm{b}^{*}$ values are much more representative of its visual color than the $L^{*}$ value (black to white or luminosity). The color values corresponding to the seed were: $28.8 \pm 0.32,0.99 \pm 0.18$, and $7.35 \pm 0.23$ for $L^{*}, a^{*}$, and $b^{*}$, respectively. The $\mathrm{L}^{*}$ value indicates a tendency toward black and brown-gray colors, which coincide with the visual appearance of this plant part, which could be explained by enzymatic and non-enzymatic browning reactions that may result in the formation of water-soluble brown, gray and black colored pigments. The visual and instrumental colors of $P$. vitifolia peel and seeds were confirmed by the color index $(-2.63 \pm 0.08$ and $4.67 \pm 0.38$, respectively) and the Whiteness Index ( $42.10 \pm 0.08$ and $28.40 \pm 0.16$, respectively). On the other hand, the texture value of $P$. vitifolia fruit $(17.80 \pm 0.08 \mathrm{~N})$ would be associated with the thickness of the peel $(58.00 \pm 1.08 \mathrm{~mm})$, which is higher compared to hardness and thickness values found in other species of the genus [26]. It is noteworthy to mention that $P$. vitifolia also has hard seeds covered with generally lignified cells.

\section{TSEs}

The results showed that ethanol extracted a higher amount $(18.90 \pm 1.32 \%$ and $16.60 \pm 1.35 \%$, seed and peel, respectively), while ethyl acetate removed the lowest quantities $(6.23 \pm 0.45 \%$ and $2.52 \pm 0.28 \%$, seed and peel, respectively). The results showed that the tendency of TSEs yield should rank in the following order: $\mathrm{TSE}_{\text {Peel' EtoAc }}<\mathrm{TSE}_{\text {Seed, EtoAc }}<\mathrm{TSE}_{\text {Peel, EtOH }}<\mathrm{TSE}_{\text {Seed, EtoH }}$. Mean values were considered statistically significant when $\mathrm{p}<0.05$. Likewise, higher TSE contents were obtained mostly from the seeds than from the peel.
Physical and chemical characterization of ethanolic extracts

The Color Index values of the ethanolic extracts $(-94.30 \pm 0.28$ and $-4.21 \pm 0.23)$ and Whiteness Index $(8.38 \pm 0.13$ and $4.64 \pm 0.28$, peel and seed, respectively) show a tendency toward brown, gray, and black colors, which coincides with the visual appearance of the two residual materials. Moreover, the byproducts do not vary significantly $(p>0.05)$. About the other evaluated characteristics: relative density at $27^{\circ} \mathrm{C}(1.06 \pm 0.09$ and $1.01 \pm 0.04)$, Brix $(20.30 \pm 0.01$ and $20.40 \pm 0.06)$, refractive index at $27^{\circ} \mathrm{C}(1.38 \pm 0.01$ and $1.33 \pm 0.00)$, absorption in UV to $365 \mathrm{~nm}$ (blue fluorescence in both extracts), $\mathrm{pH}$ at $27^{\circ} \mathrm{C}(4.90 \pm 0.10$ and $3.50 \pm 0.09)$, and titratable acidity $(2.52 \pm 0.02$ and $2.90 \pm 0.01$ in $\%$ citric acid, respectively.

\section{Nutritional and Phytochemical composition}

It is noted that the moisture content of the peel and seed was $<50 \%$, indicating high levels of dry matter (vitamins, acids, sugars, proteins, polysaccharides, phenolic compounds, and minerals, among others). The ash content, recognized as a quality parameter to assess food functional properties, is slightly different in peel and seeds $(5.60 \pm 0.22$ and $4.00 \pm 0.23 \%$, respectively). P. vitifolia seeds have crude protein twice as large $(15.50 \pm 1.13 \%)$ as the peel $(6.60 \pm 1.22 \%)$ and crude fat content in seeds $(25.6 \pm 2.25 \%)$ exceeds 5 times the one in the peel $(5.70 \pm 0.27 \%)$. Nonetheless, the crude fiber and carbohydrates in the seed $(2.80 \pm 0.21$ and $18.40 \pm 1.62 \%)$ were lower than in the peel $(11.40 \pm 1.22 \%$ and $34.00 \pm 1.58 \%$, respectively), suggesting that the fruit of this plant species contains starch, mainly in the peel. The data on the mineral content show the potassium $(6.20 \pm 0.22 \mathrm{~g} / \mathrm{g})$ and calcium $(1.70 \pm 0.17 \mathrm{mg} / \mathrm{g})$ with the highest levels in the peel, while the seeds revealed the following mineral profile: calcium $(1.30 \pm 0.12 \mathrm{mg} / \mathrm{g})$, followed by sodium $(1.10 \pm 0.13 \mathrm{mg} / \mathrm{g})$, magnesium $(0.80 \pm 0.02 \mathrm{mg} / \mathrm{g})$, potassium $(0.50 \pm 0.10 \mathrm{mg} / \mathrm{g})$, and phosphorus $(0.21 \pm 0.05 \mathrm{mg} / \mathrm{g})$. The calcium high content may be associated with the hardness/firmness of both byproducts, mainly in the fruit peel $(17.80 \pm 0.01 \mathrm{~N})$. Furthermore, among all the mineral elements analyzed, copper showed lower concentrations $(0.02 \pm 0.01$ and $0.01 \mathrm{mg} / \mathrm{g}$ dry seed and peel, respectively). Similar results were observed in the Passiflora incarnata seeds nutritional analysis [27]. The phytochemical screening results showed nine active components in both extracts, including reducing sugars, iridoids, alkaloids, saponins, triterpenes, steroids, tannins, flavonoids, and anthocyanins, the last three (phenolic compounds) are present in high amounts. Anthocyanins, tannins, flavonoids, anthraquinones, and alkaloids were more abundant in the seeds, while cyanogenic compounds and vitamins (A and C) were found mainly in the peel. Coumarins and cardiac glycosides are absent in both fruit parts.

\section{HPLC screening}

Fourteen authentic samples of phenolic compounds (proanthocyanidins, flavonoids, glycoside flavonoids, hydroxycinnamic acid derivatives, and phenolic acids) were used as reference compounds in HPLC screening. The peel ethanolic extract exhibited the following profile: Rutin (399.00 $\mu \mathrm{g} / \mathrm{g}$ sample) $>$ p-coumaric acid $(73.80 \mu \mathrm{g} / \mathrm{g}$ sample) $>$ sinapic acid (35.40 $\mu \mathrm{g} / \mathrm{g}$ sample) >chlorogenic acid (24.00 $\mu \mathrm{g} / \mathrm{g}$ sample) $>$ hyperoside $(20.00 \mu \mathrm{g} / \mathrm{g}$ sample $)>$ quercetin $(6.20 \mu \mathrm{g} / \mathrm{g}$ sample $)$. The extract seeds showed p-coumaric acid $(78.40 \mu \mathrm{g} / \mathrm{g}$ sample) and rutin $(48.80 \mu \mathrm{g} / \mathrm{g}$ sample) as the only components. According to these study findings, the byproducts from $P$. vitifolia fruit can be differentiated by their chemical fingerprint. p-Coumaric acid and rutin at a peel-to-seed ratio of $1: 1$ and $8: 1$, respectively, might be taken into account as quality chemical markers in development programs who will use this $P$. vitifolia fruit residual biomass as raw material.

\section{Physico-chemical characterization of seed oil}

According to $P$. vitifolia seed composition, the lipid content was about $25.60 \%$ (on a dry weight basis). This result is comparable to that of other Passiflora species $[28,29]$ and exceeds that of some others $[27,30]$. The refractive index value is consistent with those found for the conventional oils [31]. Furthermore, the saponification index of $P$. vitifolia seed oil is lower than the one reported for passion fruit [32,33] or soybean [31]. However, it is similar to that of corn oil [31] (Table 1). 
Table 1: Physical and chemical characteristics of seed oil

\begin{tabular}{|c|c|c|c|c|c|}
\hline Characteristics & Passiflora vitifolia & Passiflora edulis f. flavicarpa & & Soybean*** & Corn*** \\
\hline Refractive index & $1.46 \pm 0.00$ & $1.46 \pm 0.00^{*}$ & $\mathrm{NR}^{* *}$ & $1.46-1.47$ & $1.46-1.46$ \\
\hline Saponification index ${ }^{1}$ & $139 \pm 0.05$ & $191.00 \pm 2.76^{*}$ & $174.00 \pm 1.48^{* *}$ & $189-195$ & $187-195$ \\
\hline Iodine index ${ }^{2}$ & $116.00 \pm 0.07$ & $128.00 \pm 0.75^{*}$ & $110.00 \pm 5.02^{* *}$ & $124-139$ & $103-135$ \\
\hline Acidity index ${ }^{3}$ & $2.31 \pm 0.04$ & $2.35 \pm 0.06^{*}$ & $1.63 \pm 0.08 * *$ & NR & NR \\
\hline Peroxide index ${ }^{4}$ & $1.24 \pm 0.22$ & $1.46 \pm 0.03^{*}$ & $1.54 \pm 0.12^{* *}$ & NR & NR \\
\hline
\end{tabular}

NR: Not reported, ${ }^{1} \mathrm{mg} \mathrm{KOH} / \mathrm{g},{ }^{2} \mathrm{~g} \mathrm{I} / 100 \mathrm{~g},{ }^{3} \mathrm{mg} \mathrm{KOH} / \mathrm{g},{ }^{4} \mathrm{meq} / \mathrm{kg},{ }^{*}$ Taken from Malacrida CR, Jorge N [33], ${ }^{* *}$ Taken from Silva et al. [32], *** Taken from Codex Alimentarius, [31]

Iodine index for the sample analyzed is comparable to Passiflora edulis f. flavicarpa (the most marketed passionflower in Colombia [1]) and corn oil [31-34]. With the iodine index above 100, the oil can be considered as semi-drying. The acidity index value found (Table 1) is within the permissible range of quality parameters for edible vegetable oils ( $<4 \mathrm{mg} \mathrm{KOH.g/oil).} \mathrm{The} \mathrm{peroxide} \mathrm{index} \mathrm{adjusts} \mathrm{to} \mathrm{the} \mathrm{requirements}$ of the established quality parameters to crude oils (maximum value of $10 \mathrm{meq} / \mathrm{kg}$ ) [31], which verify the good quality of $P$. vitifolia seed oil.

Table 2 shows the fatty acid composition of $P$. vitifolia seed oil compared to that of $P$. edulis f. edulis, which was extracted and analyzed under the same conditions in our laboratory. $P$. vitifolia oil fatty acid profile may be described as follows: Linoleic acid (52.50\%) > oleic acid $(11.40 \%)$ $>$ palmitic acid (7.15\%) > stearic acid (1.58\%). This fatty acid profile is composed of a high percentage of unsaturated fatty acids (UFAs), a low percentage of saturated fatty acids (SFAs), and two essential fatty acids (linoleic, $\omega-6$, and linolenic, $\omega-3$, acids). Table 2 also shows that the oil of $P$. edulis $\mathrm{f}$. edulis contains a higher amount than $P$. vitifolia of linoleic acid but does neither exceed it in the total UFAs nor monounsaturated fatty acids. The fatty acid profile of $P$. vitifolia here described is comparable to that reported by Malacrida and Jorge [33] on the oil of $P$. edulis f. flavicarpa.

\section{Total phenolic content and in vitro TAP}

Table 3 presents the results of total phenolics and TAP assessment in $P$. vitifolia fruit byproducts using the ABTS, DPPH, FRAP, and ORAC methods. The total phenolic concentration ranged widely in plant material (2817 to $10671 \mathrm{mg}$ GAE.100/g/wet weight), showing significant differences between them, and an average content of $6744 \mathrm{mg}$ GAE.100/g sample. It is important to emphasize that the seed exhibited almost 4 times more phenolic compounds than the peel. These values are higher compared to those found by Moreno et al. [35] in the six pulp extracts of tropical fruits from Colombia: Banana passion fruit (Passiflora tripartita var. mollissima), gulupa (P. edulis Sims), avocado (Persea americana Mill.), lulo (Solanum quitoense Lam.), tomate de árbol (Cyphomandra betacea Sendt.), and gooseberry (Physalis peruviana L.).

According to the data showed in Table 3, the RSC was increased like this: Peel extract against ABTS < peel extract against DPPH $<$ seed extract against DPPH <seed extract against ABTS. In both tests, a lower $\mathrm{IC}_{50}$ value indicates a greater radical scavenging ability for a given sample. Furthermore, it is evident that the standard deviations of all RSC results were relatively small and the seed extracts presented a higher RSC than the peel values. The ethanolic extracts of the fruit byproducts were also tested for their FRAP and ORAC assays. The mean FRAP and ORAC were found to be 95.50 and $502.60 \mu \mathrm{mol}$ TEAC.100/g values, respectively. Both FRAP and ORAC evaluations measure directly the antioxidant activity of the sample constituents. Therefore, the higher value obtained in these assessments, the higher the AC of compounds from the plant or part of it [36]. Based on Table 3 data, in both AC methods evaluated, ethanolic extracts from the seeds are more active than those obtained with the peel.

As in the RSC assays, significant differences were also observed among the AC of the residual materials. In addition, a strong and significant Pearson's linear correlations were found between total phenolics and $\mathrm{DPPH}, \mathrm{ABTS}$, and FRAP $(\mathrm{R}=0.93,0.77$, and 1.00 respectively,
Table 2: The fatty acid composition (\%) of Passiflora vitifolia and Passiflora edulis seed oil

\begin{tabular}{lll}
\hline Methyl esters & Passiflora vitifolia & $\begin{array}{l}\text { Passiflora edulis } \\
\text { f. edulis* }\end{array}$ \\
\hline Capric (C10) & 0.03 & 0.02 \\
Tridecylic (C13) & 0.02 & 0.02 \\
Myristic (C14:0) & 0.06 & 0.03 \\
Pentadecylic (C15) & 0.02 & 0.01 \\
Palmitic (C16:0) & 7.15 & 6.13 \\
Palmitoleic (C16:1) & 0.15 & 0.12 \\
Margaric (C17) & 0.04 & 0.05 \\
Stearic (C18:0) & 1.58 & 1.33 \\
Oleic (C18:1) & 11.40 & 6.91 \\
Linoleic (C18:2) & 52.50 & 56.20 \\
Linolenic (C18:3) & 0.39 & 0.34 \\
Arachidic (C20) & 0.39 & 0.35 \\
Eicosenoic (C20:1) & 0.10 & 0.06 \\
Eicosadienoic (C20:2) & 0.07 & 0.08 \\
Behenic (C22:0) & 0.06 & 0.05 \\
UFA & 64.60 & 63.70 \\
MUFA & 11.60 & 7.09 \\
PUFA & 52.90 & 56.60 \\
PUFA/MUFA & 4.54 & 7.99 \\
SFA & 9.05 & 7.71 \\
SFA/UFA & $1 / 7.14$ & $1 / 8.26$ \\
\hline
\end{tabular}

UFA: Unsaturated fatty acids, MUFA: Monounsaturated fatty acids,

PUFA: Polyunsaturated fatty acids, SFA: Saturated fatty acids. *Source: Authors

$\mathrm{p}<0.05)$; by contrast, no positive correlation was found between total phenolic content and ORAC $(-1.00)$. Similar results were reported by Rodrigues et al. [37] and González et al. [38]. A one-way analysis of variance (ANOVA) was used to examine significant differences between byproducts, when a significant difference was found, Tukey's test was used to identify the categories that differed from one another. Differences between means at 95\% $(\mathrm{p}<0.05)$ of confidence level were considered statistically significant. Significant variations were also observed among the peel and seeds of P. vitifolia in all applied methods to evaluate the TAP.

\section{Anti-hyperglycemic activity}

The in vitro study on alpha-amylase inhibition showed that, at concentrations between 100 and $800 \mu \mathrm{g} / \mathrm{ml}$, P. vitifolia ethanolic extracts exhibited an inhibitory effect on the enzyme in a dosedependent manner. At an $800 \mu \mathrm{g} / \mathrm{ml}$ concentration, the ethanolic extracts of $P$. vitifolia fruits also exhibited significant $(\mathrm{p}<0.05)$ inhibition activities on $\alpha$-amylase enzyme between the seed and the peel (55.10 \pm 0.10 and $11.00 \pm 0.30 \% \%$, respectively). Nevertheless, the seed extract exhibited no significant $\alpha$-amylase inhibitory activity $(p>0.05$, one-way ANOVA) when compared with acarbose (47.20 $\pm 0.10 \%)$, used as positive control under the same test conditions. In this work, efforts were made to ensure that the obtained results were specific one and not purely a consequence of non-specific inactivation of the enzyme by variations in $\mathrm{pH}$.

The potential role of many medicinal plants as inhibitors of $\alpha$-amylase has been reviewed by several authors $[39,40]$. The enzyme inhibition value of $P$. vitifolia seed ethanolic extract can be considered low when compared 
Table 3: Total phenolic content and antioxidant capacity of the peel and seeds of $P$. vitifolia

\begin{tabular}{|c|c|c|c|c|c|}
\hline \multirow[t]{3}{*}{ Extract } & \multirow[t]{3}{*}{ Total phenols ${ }^{*}$} & \multicolumn{4}{|l|}{ TAP } \\
\hline & & \multicolumn{2}{|l|}{ RSC } & \multicolumn{2}{|l|}{ AC } \\
\hline & & $\mathrm{DPPH}^{* *}$ & ABTS $^{* *}$ & FRAP & ORAC \\
\hline Peel & $2817.00 \pm 8.90^{c}$ & $7.80 \pm 0.90^{c}$ & $9.32 \pm 1.10^{\mathrm{b}}$ & $44.40 \pm 2.96^{\mathrm{b}}$ & $435.20 \pm 209.00^{b}$ \\
\hline Seed & $10671.00 \pm 13.70^{\mathrm{a}}$ & $5.32 \pm 0.40^{\mathrm{a}}$ & $1.84 \pm 0.20^{\mathrm{a}}$ & $146.60 \pm 4.65^{\mathrm{a}}$ & $569.90 \pm 170.00^{a}$ \\
\hline Mean $\pm S D$ & $6744.00 \pm 11.30$ & $6.56 \pm 0.65$ & $5.58 \pm 0.65$ & $95.50 \pm 3.80$ & $502.60 \pm 189.50$ \\
\hline
\end{tabular}

${ }^{*}$ mg GAE: Gallic acid equivalents . $100 / \mathrm{g}$ sample, ${ }^{* *} \mathrm{IC}_{50}(50 \%$ inhibitory concentration), TAP: Total antioxidant potential ( $\mu$ mol/100 wet weight), RSC: Radical scavenging capacity, AC: Antioxidant capacity, FRAP: Ferric reducing antioxidant power ( $\mu$ mol TEAC [Trolox equivalent antioxidant capacity].100/g), ORAC: Oxygen radical absorbance capacity ( $\mu$ mol TEAC [Trolox equivalent antioxidant capacity].100/g); ${ }^{\text {ab,c }}$ Different letters indicate significant differences for each column ( $<<0.05$ ); GAE: Gallic acid equivalents; SD: Standard deviation

to those obtained with the Passiflora nitida leaf hydro-ethanolic extract $(63 \%$ at $130 \mu \mathrm{g} / \mathrm{ml})$ by Montefusco-Pereira et al. [41], while Passiflora ligularis pulp acetonic extract showed $82.6 \%$ at $125 \mu \mathrm{g} / \mathrm{ml}[42]$. Furthermore, thirteen plant species, requested by folk medicine by its anti-diabetic activity, were tested for alpha-amylase inhibitory activity; among them, only the $50 \%$ methanol extracts of Aloe vera L., Liliaceae, $\left(\mathrm{IC}_{50}=0.081 \mathrm{mg} / \mathrm{ml}\right)$ and Paronychia argentea Lam., Caryophyllaceae, $\left(\mathrm{IC}_{50}=0.20 \mathrm{mg} / \mathrm{ml}\right)$ exhibited more than $80 \%$ alpha-amylase inhibitory activity; nevertheless, they were about 20 and 50 times, respectively, less active than acarbose [43].

Under other test conditions, $P$. vitifolia extracts inhibition percentage on the glucose diffusion through a dialysis membrane was determined. The glucose adsorption capacity of the extracts did not experience any modification in the initial times (30-60 min). Nonetheless, from $2 \mathrm{~h}$ they changed like this: At $2 \mathrm{~h}(18.10 \pm 0.70$ peel and $69.90 \pm 0.50 \%$ seed); at $6 \mathrm{~h}(10.40 \pm 1.60$ peel and $61.80 \pm 1.60 \%$ seed $)$, and at $24 \mathrm{~h}$ $(20.10 \pm 1.90$ peel and $45.60 \pm 2.10 \%$ seed). The results of the study indicate that, in the whole test time, the seed ethanolic extract showed a higher glucose adsorption capacity when it was compared to the peel extract, and, similarly, it could bind glucose most effectively. An ANOVA test confirmed the statistically significant differences $(p<0.01)$ among the byproducts in each period. The higher effectiveness of seeds extract $(70 \%)$ was shown at $2 \mathrm{~h}$ of work; thereafter, its activity decreased and delayed its transport across the intestinal lumen until its capacity was reduced to approximately $50 \%$ at $24 \mathrm{~h}$. Pearson's correlation analysis displayed high and significant linear correlations between total phenolics and anti-hyperglycemic activity methods $(\mathrm{R}=0.98$ and 0.95 for inhibition alpha-amylase and glucose diffusion through the dialysis membrane, respectively); for all, $\mathrm{p}<0.01$. Salehi et al. [44] recently published a review grounded on multiple examples of medicinal plants with antidiabetic potential with focuses on preclinical and clinical studies. Nevertheless, the Passiflora genus does not appear registered in this study.

\section{DISCUSSION}

CIELAB, CIE L*a*b*, is a color model+space combo in which $\mathrm{L}$ is brightness and $\mathrm{a}$ and $\mathrm{b}$ are chrominance components, with the difference that the color values are beyond from the human perception. It also has imaginary colors that cannot be reproduced in the physical world. Then, the colors determined should not be dependent on the device they are displayed at the same time [45]. In general, the primary pigments that impart colors are the fat-soluble chlorophylls (green), carotenoids (yellow, orange, and red), and the water-soluble anthocyanins (red, blue), flavonoids (yellow), and betalains (red) [46]. Color index is used to determine the harvesting date or to decide if fruits should undergo a degreening treatment; meanwhile, Whiteness Index is a measure to yield number correlating closely with consumers' preferences for white colors [9].

Textural parameters of fruits and vegetables are perceived when the product is picked up by hand or placed in the mouth and chewed, these quality characteristics are easily measured using instrumental methods. It should be noted that the general quality of fruits and vegetables fresh is governed by many factors: Color, appearance, flavor, fragrance, texture and nutritional value (vitamins, antioxidants, and other healthpromoting substances), and many more additional changes that take place after harvesting, which play a very significant role in the assessment of their quality or decreased market value; these quality attributes are becoming increasingly valued by consumers, scientists, and industry. However, a considerable lack of uniformity in P. vitifolia fruit maturation makes it difficult to monitor both physiological and horticultural maturity, which is based on the sensory characteristics of the product. Hence, certain standards of maturity must be kept in mind while harvesting their fruits.

The high diversity of minerals found in the fruit byproducts reveals that they could be a good dietary supplement. The low copper contents in the samples studied may be associated mainly with the phenolic oxidation by polyphenol oxidase enzyme. It is a copper-dependent enzyme that catalyzes the oxidation of phenolics using molecular oxygen, leading to the formation of typically reddish-brown pigments. Hence, the presence of these metabolites can be related to the browning of $P$. vitifolia fruits that occurs with the advancement of maturity, besides contributing to unripe fruit bitter taste. Some mineral elements found (zinc, iron, magnesium, manganese, among others), although in very low quantity (data not shown), are important co-factors found in the structure of certain enzymes and are necessary for numerous biochemical pathways [47].

It is known there must be a close and linear relationship between the environmental factors of the plant development site, the ratio of depositary organs of secondary metabolites, and the level of concentration of these to the metabolic pathway that generates the phytoconstituents no suffer deviations. If the above does not happen, the plant will not produce the bioactive compounds that it normally biosynthesizes and the yield of the extractives will be very low, even if a suitable solvent and a relevant extraction method are applied [48]. Perhaps some of these events influenced the low yield of dry matter obtained $(<50 \%)$ in both byproducts. The correct of ethanol choice as evidenced by the diversity of secondary metabolites detected in the phytochemical analysis, including saponins. Although these types of phytocompounds have been reported for the genus Passiflora, their occurrence is restricted to just a few species [49].

Similarly, some reports indicate that the majority of the plants that are used in popular medicine for the treatment of diabetes possess chemical constituents such as alkaloids, carbohydrates, coumarins, flavonoids, terpenoids, phenolic substances, and among others [50]. Many of these compounds were found in P. vitifolia byproducts ethanolic extracts, showing a promising future as new hypoglycemiant agents and suggesting the possibility of being used as phytotherapeutic agents. Medicinal plants may act as an alternative source of antidiabetic agents [44]. Furthermore, both extracts displayed the presence of routine and p-coumaric acid. The first mentioned compound has shown its multispectrum pharmacological benefits for the treatment of various chronic diseases, such as cancer, diabetes, hypertension, and hypercholesterolemia [51]; meanwhile, p-coumaric acid is an 
antioxidant, which is implicated for the prevention of pathologies such as inflammatory diseases like heart diseases and cancer [52]. Likewise, these metabolites could be used as chemomarkers, which is crucial for the identification of a plant or some of its parts. Furthermore, chemical markers could be unique components that contribute to the therapeutic effects of herbal medicine [53]. Furthermore, harmala-type alkaloids were found, for example, harmane, harmine, harmaline, harmol, and harmalol. This category of alkaloid has been used therapeutically to treat sleep disorders, depression, and monoamine oxidase inhibitors, which would give antidepressant rather than sedative effects and also acts as a vasorelaxant [54].

The seeds of $P$. vitifolia exhibit oil content similar to that of other oilseeds, whose oils find application in the food or cosmetic industry. The yield could be influenced by the extraction technique, the type of solvent, the operating conditions, and the geographical areas where this fruit is grown $[28,33,34]$. In addition, the good quality of the oil from seeds can be verified by the physical and chemical characteristics, which were consistent with those found for the conventional oils such as soybean and corn [31]. Based on the yield and fatty acid composition, P. vitifolia seeds could be utilized as an additional source of edible oil in our country.

The results showed that the total phenolic content was higher compared to other fruits, for example, strawberries, raspberries, blueberries, blackberries [37] and recognized as a source of phenolic compounds; nevertheless, they moderately differ from the values found in some highly commercialized Passiflora species [55]. These differences could be influenced by the plant geographical origin, the efficacy of the phytophenols recovery solvent, development conditions of cultivar, harvesting, and drying method; it could also be taken into account the equivalent unit in which the results are expressed. The determination of phenolic compounds is important since these phytoconstituents can act as antioxidants, structural polymers (lignin), attractants (flavonoids and carotenoids), UV screens (flavonoids), signal compounds (salicylic acid and flavonoids), and defense response chemicals (tannins and phytoalexins). In the human being, phenolic compounds are vital in defense responses, such as antioxidant, anti-aging, anti-inflammatory, and antiproliferative activities $[55,56]$.

There is considerable debate about which method is best to measure antioxidant potential. Hence, the DPPH method is commonly accepted to test the ability of compounds to act as free radical scavengers or hydrogen donors. ABTS assay is based on the capacity of different components to scavenge the radical cation $\mathrm{ABTS}^{++}$compared to a standard antioxidant as ascorbic acid or Trolox [57]. Ferric reducing of antioxidant power (FRAP) test is based on an electron transfer to colored oxidants in a redox reaction. Despite the method does not quickly detect some antioxidants such as glutathione, it may be considered suitable for the assessment of the antioxidant activity of fruit samples because only limited amounts of plant glutathione are absorbed by humans [58]. ORAC assay is based on the oxidation of a fluorescent probe by peroxyl radicals by means of a hydrogen atom transfer process. In the assessment, antioxidants and substrate compete for thermally generated peroxyl radicals; it combines both inhibition percentage and inhibition time of the reactive species action by antioxidants into a single quantity $[22,36]$. Then, the assay provides information about the scavenging capacity of antioxidants against the peroxyl radical (RSC), and also it measures the activity of all the antioxidants inherently present in the plant (AC). Nevertheless, the TAP of extracts should not be attributed exclusively to phenolic compounds because the synergism between these metabolites and other substances present may contribute to the global antioxidant activity of the sample; further, a large amount of non-phenolic substances (sugars, organic acids, proteins, etc.) can also interfere in phenolic antioxidant activity $[59,60]$.

The in-vitro alpha-amylase enzyme inhibition assay uses drugs such as acarbose, miglitol, or voglibose as a model to evaluate phytoconstituent's action capable of contributing to starch and glycogen degrading and their subsequent absorption as glucose. Medicinal plants, or their parts, reveal that this property could be used for treating diabetes and obesity [61], causing a marked delay of glucose absorption and thereby in the decreasing of post-prandial plasma glucose levels [42]. Postprandial hyperglycemia is a prime characteristic of diabetes mellitus and has been a focus in the therapy for type-2 diabetes mellitus [62]. The alpha-glucosidase inhibitors, for example, acarbose, reduce the post-prandial glycemia peak by $20 \%$ [41]. However, this medicine has adverse effects directly related to the dose, the most common are gastrointestinal disorders such as flatulence, bloating, and abdominal distension, attributable to the changed digestion of starch by the strong inhibition of intestinal $\alpha$-amylase [62]. According to some researchers, the extracts most effective in inhibiting alpha-amylase, such as strawberry, raspberry, red grape, and green tea, among others, contain appreciable amounts of soluble tannins [63]. Nonetheless, Passiflora species extracts are richer in flavonoids than tannins $[7,38]$.

The glucose diffusion inhibition, or the dialysis tube technique, was applied as a simple model that simulates the potential of soluble dietary fibers to delay the diffusion and movement of glucose in the intestinal tract [64]. The ability of plants to inhibit the absorption of glucose with the viscosity of soluble polysaccharides suggests that the antihyperglycemic action may be due to the decrease of the metabolite's absorption functionality in vivo [24]. Some researchers argue that the model used, despite the constant agitation applied, which mimics gastrointestinal movement, has limitations associated with testing time $(2-26 \mathrm{~h})$ because this moment is not directly comparable with the temporal space of the cellular mechanisms of glucose absorption in the intestine since glucose is a carbohydrate that is rapidly absorbed in the small intestine and takes no more than $3 \mathrm{~h}$ to reach the bloodstream [65]. It must be remembered that the ethanolic extract of seeds showed its highest effectiveness $(70 \%)$ at $2 \mathrm{~h}$. It could also be thought that the predominance of phenols in this plant part could be strongly compromised with the inhibition of the glucose diffusion through the dialysis membrane in the first $2 \mathrm{~h}$ of evaluation. Thus, it can be proposed that the delaying effect of the seed constituents is worth considering. Consequently, it can be thought that the use of products derived from this $P$. vitifolia fruit byproduct would be greatly beneficial to reduce the rate of digestion and absorption of carbohydrates from the intake, which would improve the quality of life of the hyperglycemic patient. However, a greater number of tests is required to corroborate it.

Great variability, high availability, low cost, and the least side effects make of plant preparations the main key of frequent therapies performed in rural areas. In recent decades, several studies have indicated the value of vegetable fiber or complex carbohydrates, including highly viscous soluble fibers, for the control of blood glucose concentrations [66]. Furthermore, it had been reported that the phenolic-rich plant extracts have a higher ability to inhibit the $\alpha$-amylase enzyme and that, particularly phenols, exhibit an $\alpha$-amylase and $\alpha$-glucosidase inhibitory activity in a dependent manner on the phenolic profile $[37,67,68]$. In this work, a higher content of fiber was found in the peel $(11.40 \%)$ than in the seed $(2.80 \%), \mathrm{p}<0.05$ between the values; the seed, in turn, showed almost 6 times more phenolic constituents than the peel. Therefore, the greater anti-hyperglycemic activity from the seeds ethanolic extract could be associated more with its phenolic availability than the fiber content. Thus, it could be thought that the predominance of phenols in this plant part could be strongly compromised with the inhibition of the diffusion of glucose through the dialysis membrane in the first $2 \mathrm{~h}$ of action; this can be relevant for the treatment of type-2 diabetes mellitus [69]. Besides, several works report a wide range of functionalities that have been scientifically proven for the Passiflora genus, many of which have been supported by the composition of certain bioactive compounds [38,70-72]. These studies have in common with the present work that the activities have been correlated with the phenolic constituents.

\section{CONCLUSIONS}

The exploratory evaluation of physicochemical parameters and nutritional composition of residual biomass, such as $P$. vitifolia peel and 
seed, can be a viable economic alternative because it adds value to the plant product as a source of bioactive compounds. This supports the idea of proposing the fruit byproducts of $P$. vitifolia, an unconventional passionflower, in animal feed and suggests its potential use as a promising product. In addition, a broad spectrum of pharmacological benefits is expected, considering phytochemical characteristics and nutritional content of the seeds, which would allow them to be used as a raw material in various industries. The high positive relationship evidenced among phenolic content, the antioxidant potential and the anti-hyperglycemic activity reveals the true biological value of the fruit byproducts from $P$. vitifolia. This study has shown that the delaying effect of the constituents of $P$. vitifolia seed is worth considering to mitigate post-prandial hyperglycemia and ameliorate oxidative stress. Further studies are required to confirm this information. From the physicochemical characterization, $P$. vitifolia seed oil may be used as cooking oil or in cosmetology. This appears to be the first work to study the physical and chemical properties of $P$. vitifolia peel and seeds in our country; the information provided here could be helpful in the development of new food functional products.

\section{ACKNOWLEDGMENTS}

The authors acknowledged the Natural Products Research Group, GIPRONUT, and LASEREX laboratories from UT y. The support of the Chemistry Department, ETSEA, University of Lleida, Spain, is highly appreciated. This work was supported financially by the Research and Scientific Development Office, UT (Project number: 250220516).

\section{AUTHORS' CONTRIBUTIONS}

All authors have equally contributed to the drafting, reviewing, and editing of the manuscript.

\section{CONFLICTS OF INTEREST}

There are no conflicts of interest.

\section{AUTHORS' FUNDING}

We thank Research and Scientific Development Office, Tolima University, for funding the project.

\section{REFERENCES}

1. Ocampo J, D'Eeckenbrugge GC, Jarvis A. Distribution of the genus Passiflora L. diversity in Colombia and its potential as an indicator for biodiversity management in the coffee growing zone. Diversity 2010;2:1158-80.

2. Macdougal JM, Coca LF. Passiflora kumandayi (Passifloraceae), a new species from the Colombian Andes in a new section within subgenus Decaloba. Phytotaxa 2018;344:13-23.

3. Wanderley MD, Shepherd GJ, Giulietti AM, Longhi-Wagner HM, Bittrich V. Flora Fanerogâmica Do Estado de São Paulo. Vol. 1. São Paulo: Hucitec; 2001.

4. Ramírez W. Hibridación Interespecífica en Passiflora (Passifloraceae), Mediante Polinización Manual, y Características Florales Para la Polinización. Costa Rica: Lankesteriana; 2006.

5. Aguirre-Morales AC, Bonilla-Morales MM, Caetano CM. Evaluation of diversity and distribution patterns of Passiflora subgenus Astrophea (Passifloraceae) in Colombia. A challenge for taxonomic, floristic and conservation research of the species. Acta Agron 2016;65;422-30.

6. Sakalem ME, Negri, G, Tabach R. Chemical composition of hydroethanolic extracts from five species of the Passiflora genus. Rev Bras Farmacogn 2012;22:1219-32.

7. Rodriguez AA. Potencial Antihipertensivo y Antioxidante de Extractos Etanólicos Obtenidos de Semillas de Passiflora vitifolia Kunth y Passiflora edulis Sims var. edulis. Spanish: Universidad Nacional de Colombia-Sede Bogotá; 2018.

8. Tavhare SD, Nishteswar K. Collection practices of medicinal plantsVedic, Ayurvedic and modern perspectives. Int J Pharm Biol Sci Arch 2014;5:54-61.

9. Duprat F, Grotte M, Loonis D, Pietri E. Etude de la possibilité de mesurer simultanément la fermeté de la chair et de l'épiderme des pommes. Sci Aliments 2000;20:253-64.
10. Horwitz W, editor. Official Methods of Analysis of AOAC International. In: Agricultural Chemicals, Contaminants, Drugs. Vol. 1. Gaithersburg, Maryland: AOAC International; 1997.

11. Patel MR. Pharmacognostic and phytochemical evaluation of Gymnema sylvestre leaf. World J Pharm Sci 2017;6:1532-8.

12. Barcelo R. Phytochemical screening and antioxidant activity of edible wild fruits in Benguet, Cordillera administrative region, Philippines. Electron J Biol 2015;11:80-9.

13. Delpino-Rius A, Eras J, Vilaró F, Cubero MÁ, Balcells M, CanelaGarayoa R. Characterisation of phenolic compounds in processed fibres from the juice industry. Food Chem 2015;172:575-84

14. Horwitz W, Latimer GW. Official Methods of Analysis of AOAC International. $3^{\text {rd }}$ ed. Gaithersburg, Maryland: AOAC International; 2010.

15. Tomàs A, Tor M, Villorbina $\mathrm{G}$, Canela R, Balcells M, Eras J. A rapid and reliable direct method for quantifying meat acylglycerides with monomode microwave irradiation. J Chromatogr A 2009;1216:3290-5.

16. Dallali S, Llovera M, Joli JE, Houcine S, Canela-Garayoa R. Rapid Gas chromatographic determination of free fatty acids in rosemary (Rosmarinus officinalis L.) leaves. Anal Lett 2016;49:467-76.

17. National Institute of Standards and Technology. Automated Mass Spectral Library with Search Program (Data Version: NIST11, Version 2.0). Gaithersburg, MD, USA: National Institute of Standards and Technology; 2010.

18. Makkar HP. Quantification of Tannins in Tree and Shrub Foliage: A Laboratory Manual. Berlin, Germany: Springer Science and Business Media; 2003.

19. Braca A, Sortino C, Politi M, Morelli I, Mendez J. Antioxidant activity of flavonoids from Licania licaniaeflora. J Ethnopharmacol 2002;79:379-81.

20. González D, Marquina R, Rondón N, Rodríguez-Malaver AJ, Reyes R. Effects of aerobic exercise on uric acid, total antioxidant activity, oxidative stress, and nitric oxide in human saliva. Res Sports Med 2008; $16: 128-37$

21. Berker KI, Güçlü K, Tor İ, Apak R. Comparative evaluation of Fe (III) reducing power-based antioxidant capacity assays in the presence of phenanthroline, batho-phenanthroline, tripyridyltriazine (FRAP), and ferricyanide reagents. Talanta 2007;72:1157-65.

22. Ou B, Hampsch-Woodill M, Prior RL. Development and validation of an improved oxygen radical absorbance capacity assay using fluorescein as the fluorescent probe. J Agric Food Chem 2001;49:4619-26.

23. Keerthana G, Kalaivani MK, Sumathy A. In-vitro alpha amylase inhibitory and anti-oxidant activities of ethanolic leaf extract of Croton bonplandianum. Asian J Pharm Clin Res 2013;6:32-6.

24. Gallagher A, Flatt P, Duffy G, Abdel-Wahab Y. The effects of traditional antidiabetic plants on in vitro glucose diffusion. Nutr Res 2003;23:413-24.

25. Negrulescu A, Patrulea V, Mincea MM, Ionascu C, Vlad-Oros BA, Ostafe V. Adapting the reducing sugars method with dinitrosalicylic acid to microtiter plates and microwave heating. J Brazil Chem Soc 2012;23:2176-82.

26. Alexander RS, Junior KR, Chagas K, Siqueira AL, Schmildt ER, Lopes JC. Physical and chemical characterization of sweet passion fruits genotypes in Sao Mateus, Espírito Santo State, Brazil. Comun Sci 2018;9:363-71.

27. Liu S, Yang F, Li J, Zhang C, Ji H, Hong P. Physical and chemical analysis of Passiflora seeds and seed oil from China. Int J Food Sci Nutr 2008;59:706-15.

28. Rana VS, Blazquez AM. Fatty acid composition of Passiflora edulis Sims Seed oil. J Lipid Sci Technol 2008;40:65-6.

29. Regis SA, Resende ED, Antoniassi R. Oil quality of passion fruit seeds subjected to a pulp-waste purification process. Ciênc Rural 2015;45:977-84.

30. Nyanzi SA, Carstensen B, Schwack W. A comparative study of fatty acid profiles of Passiflora seed oils from Uganda. J Am Oil Chem Soc 2005;82:41-4

31. Normas Internacionales de los Alimentos. Codex Alimentarius. Norma Para Aceites Vegetales Especificados Codex Stan 210. Normas Internacionales de los Alimentos; 2015. p. 1-14.

32. Silva LJ, Dias DC, Oliveira GL, Júnior RA. The effect of fruit maturity on the physiological quality and conservation of Jatropha curcas seeds. Rev Ciênc Agron 2017;48:487-95.

33. Malacrida CR, Jorge N. Yellow passion fruit seed oil (Passiflora edulis f. flavicarpa): Physical and chemical characteristics. Braz Arch Biol Technol 2012;55:127-34

34. Bello MO, Akindele TL, Adeoye DO, Oladimeji A. Physicochemical properties and fatty acids profile of seed oil of Telfairia occidentalis hook, F. Int J Basic Appl Sci 2011;11:9-14. 
35. Moreno E, Ortiz BL, Restrepo LP. Total phenolic content and antioxidant activity of pulp extracts of six tropical fruits. Rev Colomb Química 2014;43:41-8

36. Rafiq M, Azeemuddin M, Anturlikar SD, Viswanatha GL, Patki PS. Application of oxygen radical absorbance capacity (ORAC) assay in the estimation of antioxidant value of botanicals. Oxid Antioxid Med Sci 2012;1:87-90.

37. Rodrigues E, Poerner N, Rockenbach II, Gonzaga LV, Mendes CR, FettR. Phenolic compounds and antioxidant activity of blueberry cultivars grown in Brazil. Food Sci Technol 2011;31:911-7.

38. González L, Álvarez A, Murillo E, Guerra C, Méndez J. Potential uses of the peel and seed of Passiflora edulis sims f. edulis (gulupa) from its chemical characterization, antioxidant, and antihypertensive functionalities. Asian J Pharm Clin Res 2019;104-12.

39. Sudha P, Zinjarde SS, Bhargava SY, Kumar AR. Potent $\alpha$-amylase inhibitory activity of Indian Ayurvedic medicinal plants. BMC Complemnt Altern Med 2011;11:5.

40. Meza DL, Rosas SA. Inhibitory activity of alpha-amylase and total phenols in Smallanthus sonchifolius (yacon) ethanolic leaf extracts. Rev Cuba Plant Med 2014;19:310-8.

41. Montefusco-Pereira CV, de Carvalho MJ, de Araújo Boleti AP, Teixeira LS, Matos HR, Lima ES. Antioxidant, anti-inflammatory, and hypoglycemic effects of the leaf extract from Passiflora nitida Kunth. Appl Biochem Biotechnol 2013;170:1367-78.

42. Saravanan S, Parimelazhagan T. In vitro antioxidant, antimicrobial and anti-diabetic properties of polyphenols of Passiflora ligularis Juss fruit pulp. Food Sci Hum Well 2014;3:56-64.

43. Abu Soud RS, Hamdan LI, Afifi FU. Alpha amylase inhibitory activitv of some plant extracts with hypoglycemic activitv activity. Sci Pharm 2004; $72: 25-33$

44. Salehi B, Ata A, Kumar NV, Sharopov F, Ramírez-Alarcón K, RuizOrtega A, et al. Antidiabetic potential of medicinal plants and their active components. Biomolecules 2019;9:551.

45. Barrett DM, Beaulieu JC, Shewfelt R. Color, flavor, texture, and nutritional quality of fresh-cut fruits and vegetables: Desirable levels, instrumental and sensory measurement, and the effects of processing. Crit Rev Food Sci Nutr 2010;50:369-89.

46. Pathare PB, Opara UL, Al-Said FAJ. Colour measurement and analysis in fresh and processed foods: A review. Food Bioprocess Tech 2013;6:36-60.

47. Soetan K, Olaiya C, Oyewole O. The importance of mineral elements for humans, domestic animals and plants a review. Afr J Food Sci 2010;4:200-22.

48. Jato JL. Tecnología Farmacéutica Volumen II: Formas Farmacéuticas. Madrid: Editorial Síntesis; 2001.

49. Birk CD, Provensi G, Gosmann G, Reginatto FH, Schenkel EP. TLC fingerprint of flavonoids and saponins from Passiflora species. J Liq Chromatogr Relat Technol 2005;28:2285-91

50. Gupta RK, Kesari AN, Murthy P, Chandra R, Tandon V, Watal G. Hypoglycemic and antidiabetic effect of ethanolic extract of leaves of Annona squamosa L. in experimental animals. J Ethnopharmacol 2005;99:75-81.

51. Al-Dhabi NA, Arasu MV, Park CH, Park SU. An up-to-date review of rutin and its biological and pharmacological activities. EXCLI J 2015;14:59.

52. Boz H. p-Coumaric acid in cereals: Presence, antioxidant and antimicrobial effects. Int J Food Sci Tech 2015;50:2323-8

53. García AÁ, Carril EP. Metabolismo secundario de plantas. Reduca (Biologia) 2009;2:119-45.

54. Ingale A, Hivrale A. Pharmacological studies of Passiflora sp. and their bioactive compounds. Afr J Plant Sci 2010;4:417-26.

55. Ramaiya SD, Bujang JS, Zakaria MH. Assessment of total phenolic, antioxidant, and antibacterial activities of Passiflora species. Sci World J 2014:2014:167309.

56. Lin D, Xiao M, Zhao J, Li Z, Xing B, Li X, et al. An overview of plant phenolic compounds and their importance in human nutrition and management of Type 2 diabetes. Molecules 2016;21:1374

57. Moharram H, Youssef M. Methods for determining the antioxidant activity: A review. Alex J Food Sci Technol 2014;11:31-42.

58. Pellegrini N, Serafini M, Colombi B, Del Rio D, Salvatore S, Bianchi $\mathrm{M}$, et al. Total antioxidant capacity of plant foods, beverages and oils consumed in Italy assessed by three different in vitro assays. Nutr J 2003;133:2812-9.

59. Mitsuhashi S, Saito A, Nakajima N, Shima H, Ubukata M. Pyrogallol structure in polyphenols is involved in apoptosis-induction on HEK293T and K562 cells. Molecules 2008;13:2998-3006.

60. Gupta D. Methods for determination of antioxidant capacity: A review. Int J Pharm Sci Res 2015;6:546.

61. Meza DL, Rosas SA. Actividad inhibitoria alfa-amilasa y fenoles totales en extractos etanólicos de hojas de Smallanthus sonchifolius (yacón). Rev Cuba Plant Med 2014;19:310-8.

62. Kim SH, Jo SH, Kwon YI, Hwang JK. Effects of onion (Allium cepa L.) extract administration on intestinal $\alpha$-glucosidases activities and spikes in postprandial blood glucose levels in SD rats model. Int J Mol Sci 2011;12:3757-69.

63. McDougall GJ, Shpiro F, Dobson P, Smith P, Blake A, Stewart D. Different polyphenolic components of soft fruits inhibit $\alpha$-amylase and $\alpha$-glucosidase. J Agric Food Chem 2005;53:2760-6.

64. Im HJ, Yoon KY. Production and characterisation of alcohol-insoluble dietary fibre as a potential sourcefor functional carbohydrates produced by enzymatic depolymerisation of buckwheat hulls. Czech J Food Sci 2015;33:449-57.

65. MacMillan N. Utilidad del índice glicémico en nutrición deportiva. Rev Chil Nutr 2002;29:92-7.

66. Wood P, Beer M, Butler G. Evaluation of role of concentration and molecular weight of oat $\beta$-glucan in determining effect of viscosity on plasma glucose and insulin following an oral glucose load. Br J Nutr 2000;84:19-23.

67. Shobana S, Sreerama Y, Malleshi N. Composition and enzyme inhibitory properties of finger millet (Eleusine coracana L.) seed coat phenolics: Mode of inhibition of $\alpha$-glucosidase and pancreatic amylase. Food chem 2009;115:1268-73.

68. Gayathri GA, Gayathri M. Preliminary qualitative phytochemical screening and in vitro hypoglycemic potential of Acanthus ilicifolius and Evolvulus emerginatus. Int J Pharm Pharm Sci 2014;6:362-5.

69. Kang BH, Racicot K, Pilkenton S, Apostolidis E. Evaluation of the in vitro anti-hyperglycemic effect of Cinnamomum cassia derived phenolic phytochemicals, via carbohydrate hydrolyzing enzyme inhibition. Plant Foods Hum Nutr 2014;69:155-60.

70. Corrêa RC, Peralta RM, Haminiuk CW, Maciel GM, Bracht A, Ferreira IC. The past decade findings related with nutritional composition, bioactive molecules and biotechnological applications of Passiflora spp. (passion fruit). Trends Food Sci Tech 2016;58:79-95.

71. Gadioli IL, da Cunha MD, de Carvalho MV, Costa AM, Pineli LL. A systematic review on phenolic compounds in Passiflora plants: Exploring biodiversity for food, nutrition, and popular medicine. Crit Rev Food Sci Nutr 2018;58:785-807.

72. Sujana N, Ramanathan S, Vimala V, Sundaram M, Pemaiah B. Antitumour potential of Passiflora incarnata against ehrlich ascites carcinoma. Int J Pharm Pharm Sci 2012;4:10-3 